\title{
Środowisko człowieka i jego percepcja - kształtowanie przyjaznych oraz nieprzyjaznych przestrzeni mieszkalnych
}

\section{Wojciech Kocki}

Politechnika Lubelska, Wydziat Budownictwa i Architektury,

Katedra Architektury, Urbanistyki i Planowania Przestrzennego

\section{Jacek Bogucki}

Uniwersytet Medyczny w Lublinie

\section{Wioletta Tuszyńska-Bogucka}

Wyższa Szkoła Ekonomii i Innowacji w Lublinie

\section{Jarosław Pełka}

Wyższa Szkoła Ekonomii i Innowacji w Lublinie

\section{Bartłomiej Kwiatkowski}

Politechnika Lubelska, Wydziat Budownictwa i Architektury,

Katedra Architektury, Urbanistyki i Planowania Przestrzennego

\begin{abstract}
Streszczenie: Celem artykułu jest ukazanie, występujących w tkance miejskiej barier utworzonych przez człowieka. Bariery rozróżniono ze względu na ich charakter tj. od wizualnych, materialnych poprzez przestrzenne aż do niematerialnych, psychologicznych związanych z podziałami społeczeństwa na wielu płaszczyznach. W pracy zwrócono szczególną uwagę na jakość środowiska mieszkalnego na przykładzie osiedli jednorodzinnych oraz wielorodzinnych Lublina z uwzględnieniem granic tych obszarów oraz ich wzajemnego przenikania się. Poprzez analizy wybranych przestrzeni, w oparciu o aspekty psychologiczne i sensualne w jej odbiorze, ukazano zbiór cech mogących wpływać na jakość przestrzeni oraz jej odbiór w ramach definicji przyjaznej oraz nieprzyjaznej przestrzeni. Wyniki przeprowadzonych analiz są wstępem do dalszych badań w tym zakresie.
\end{abstract}

Słowa kluczowe: środowisko człowieka, przestrzeń prywatna, przestrzeń publiczna, projektowanie, psychologia

\section{Wprowadzenie}

Nadrzędnym celem podjętych rozważań jest identyfikacja oraz opis czynników mających wpływ na postrzeganie przestrzeni mieszkalnych poprzez ich użytkowników jako przyjazne bądź nieprzyjazne, z uwzględnieniem aktualnej wiedzy psychologicznej a także architektonicznej.

Efektem prowadzonych studiów będzie próba określenia uniwersalnej procedury badawczej, pozwalającej wyodrębnić te czynniki, które umożliwią tworzenie w przyszłości przestrzeni mieszkalnych i użytkowych przyjaznych człowiekowi. 
Poniższe studium jest istotne pod względem celu badań które może wykazać związek pomiędzy przestrzenią w jakiej znajduje się człowiek i jej wpływu na stan emocjonalny, który warunkuje takie aspekty jak efektywność pracy oraz nauki, wydajność pracownika, możliwość wyciszenia, skupienia bądź rozdrażnienia itp.

\section{Aspekty psychologiczne w odbiorze przestrzeni}

Obecnie podejście systemowe, traktujące człowieka a także jego otoczenie oraz sposób łączenia rozmaitych elementów wiedzy w sposób holistyczny, stosuje się do rozwiązywania tak ważnych i różnorodnych problemów, jak zanieczyszczenie otoczenia, problemy społeczno-demograficzne czy też w zakresie planowania urbanistyki [1], tak, aby otoczenie w jak największym stopniu odpowiadało na zapotrzebowania jednostek oraz społeczności ją zamieszkujących i użytkujących. W ostatnich latach powstała więc stosunkowo nowa dziedzina nauki, zwana psychologią środowiskową, zajmującą się badaniem relacji zachodzących między zachowaniem i doświadczeniem ludzkim a sztucznymi i naturalnymi środowiskami.

Psychologia środowiska zajmuje się środowiskiem na dwóch różnych „poziomach”:

a. Traktuje je jako kontekst ludzkich zachowań. Zachowania ludzi w określonym środowisku stają się zrozumiałe tylko wtedy, gdy uwzględnimy jego specyficzny kontekst (np. w zależności od charakteru obiektu lub przestrzeni zachowania będą odmienne);

b. Rozpatruje środowisko jako zbiór specyficznych możliwości i jakie ono ludziom oferuje (tzw. afordancji) a także ograniczeń, które determinują nasze zachowania. Cechy fizyczne środowiska mogą więc sprawić (ułatwić), że pewne działania są możliwe, inne - utrudnione, a jeszcze inne - niemożliwe.

W realizacji niniejszych założeń niezbędnym wydaje się więc łączenie wiedzy różnych dziedzin, zaś w prezentowanym przypadku dotyczyć to będzie architektury i psychologii. Z psychologii środowiskowej wyłoniła się psychologia architektury (lub środowiska zbudowanego - Built Environment), nowy obszar interdyscyplinarnych badań intensywnie rozwijany w ostatnich latach (Environment Behaviors Studies - EBS).

Podstawą niniejszej pracy stało się założenie, że środowisko może pobudzać lub blokować ludzką aktywność, tworząc tytułowe przyjazne bądź nieprzyjazne środowisko życia. Za podstawy niniejszych rozważań przyjęto następujące założenia teoretyczne:

- psychologiczny model zależności [2] A. Mehrabiana i J. A. Russella, ukazujący, iż cechy sensoryczne środowiska (kolory, faktury, kształty, itp.) mogą wywołać trzy podstawowe stany emocjonalne: przyjemności-pobudzenia-dominacji. Mają one z kolei związek z zachowaniami unikanie vs. dążenie (zbliżenie), typowymi dla człowieka, a nader ważnymi w inicjowaniu i podtrzymywaniu relacji społecznych (bądź ich unikaniu);

koncepcję Humphry Osmonda [3], uznającą, że istnieją dwa główne typy przestrzeni:

$\square$ odspołeczna - tj. taka, która nie wpływa na liczbę stosunków międzyludzkich (a niekiedy ją wręcz ogranicza);

$\square$ dospołeczną - a więc przestrzeń, dzięki której jej użytkownicy/członkowie mają realną możliwość zawierania i podtrzymywania stosunków społecznych;

- czterostopniową koncepcję struktury dostępności M. Czyńskiego, wyróżniającą:

$\square$ przestrzeń publiczna (ogólnodostępna),

półpubliczna (np. szkoła, kawiarnia),

półprywatna (ograniczona do pewnej grupy znanych sobie osób),

przestrzeń prywatna [4].

Właśnie te elementy, a więc sensoryczność pozytywna środowiska (bogactwo oraz określona konfiguracja faktur, kolorów i kształtów), jego dospołeczność (brak barier architektonicznych, możliwość nawiązywania kontaktów społecznych, itp.) oraz adekwatność dostępności wydają się być podstawowymi determinantami przyjazności bądź nieprzyjazności przestrzeni życia człowieka, zwłaszcza tej o charakterze przestrzeni publicznej. 


\section{Najnowsze technologie badawcze szansą dla tworzenia wizji przyjaznych przestrzeni mieszkalnych - neuroobrazowanie mózgu, eye tracking, face tracking}

W ostatnich latach możemy zaobserwować bardzo dynamiczny rozwój technologii umożliwiających badanie ludzkiego mózgu (neuroobrazowanie) oraz aktywności poszczególnych zmysłów człowieka (np. eye tracking). Odpowiednia konfiguracja poszczególnych urządzeń daje możliwość zbadania reakcji emocjonalnych człowieka na poszczególne elementy środowiska, w którym się znajduje, w ujęciu bardzo szerokim - urbanistycznym czyli miasto, dzielnica, czy osiedle, jak również w ujęciu węższym, a więc w wymiarze wnętrza architektonicznego. Dzięki szerokiemu spektrum dostępnego sprzętu i oprogramowania możliwe jest prowadzenie badań zarówno w warunkach naturalnych (wewnętrznych i zewnętrznych), jak również laboratoryjnych. Wykorzystanie do badań omawianych tutaj urządzeń może w bardzo istotny sposób umożliwić wyłonienie tych elementów otoczenia człowieka, które mogą wpływać na jego funkcjonowanie, co może w dużym stopniu umożliwić bądź ułatwić architektom projektowanie przestrzeni przyjaznych człowiekowi.

\section{Neuroobrazowanie mózgu}

Ludzki mózg i jego funkcjonowanie od dawna intryguje badaczy i jest przedmiotem wielu badań. To właśnie ludzki mózg odpowiedzialny jest za odczuwanie emocji. We wcześniejszych latach badacze starali się odnaleźć struktury ogólnie odpowiedzialne za występowanie emocji. Obecnie odchodzi się od tego założenia na rzecz poszukiwania struktur ludzkiego mózgu odpowiedzialnych za występowanie poszczególnych rodzajów emocji [5]. EEG dokonuje zapisu aktywności elektrycznej kory mózgowej. Trzy najważniejsze elementy urządzenia to czepek, głowica oraz komputer. Czepek EEG zbiera ładunki elektryczne ze skóry głowy, następnie trafiają one do głowicy, która dokonuje ich wzmocnienia po to byśmy mogli otrzymać zapis aktywności bioelektrycznej mózgu na ekranie monitora [6]. Urządzenia stosowane w badaniach różnią się dokładnością pomiaru i mogą zostać wykorzystane w różnych warunkach. Część z nich (na przykład EEG firmy EGl), zawiera czepek składający się z 256 elektrod (tzw. Gęste EEG). Jego największą zaletą jest bardzo wysoki poziom dokładności badania - minusem natomiast jest to, że badania przy jego użyciu możemy prowadzić wyłącznie w warunkach laboratoryjnych. Ciekawym przykładem może być dość prosty system Emotiv EPOC+. Jest to bezprzewodowe, mobilne urządzenie EEG, zbierające sygnał z 14 kanałów. Dużym plusem w tym przypadku jest mobilność co umożliwia nam badania poza laboratorium oraz niski koszt urządzenia - minusem natomiast jest dużo mniejsza dokładność badania w zestawieniu z wcześniej omawianym urządzeniem. Alternatywną formą badania procesów mózgowych jest funkcjonalny rezonans magnetyczny fMRI (functional magnetic rezonance imaging). Metoda ta daje nam bardzo wartościowy materiał badawczy, ale na dzień dzisiejszy jest ona bardzo kosztowna.

\section{Eye tracking (okulografia)}

Ciekawą i szybko rozwijającą się metodą badań w psychologii, a szczególnie w psychologii konsumenta jest Eye Tracking polegający na badaniu aktywności okoruchowej człowieka. Wykorzystywanie do badań eye trackerów zwiększa się, ale należy tutaj zaznaczyć, że nie jest to metoda łatwa, a dostępność szkoleń jest bardzo mała, co może zniechęcać badaczy [7]. Podstawą badań eye trackingowych jest założenie, że osoba badana najczęściej spogląda na tą część sceny wizualnej, o której myśli lub ma ona dla niej jakieś szczególne znaczenie. Istotny jest również czas poświęcony na oglądanie poszczególnych elementów sceny wizualnej, gdyż świadczy on o zainteresowaniu. Dokonując analizy materiału badawczego koncentrujemy się na fiksacjach (czas fiksacji, ich liczba, skupienie punktów fiksacji wskazujące nam obszary zainteresowań AOI) oraz sakadach (sumaryczny czas sakad, ich liczba) [8]. Obecnie wykorzystywane w badaniach urządzenia - eye trackery mogą mieć charakter stacjonarny (mające najczęściej zastosowanie w badaniach laboratoryjnych) lub mobilny. Podobnie jak w przypadku systemów EEG, tak i tutaj mobilność urządzenia wiąże się z otrzymaniem mniej dokładnego materiału badawczego. 


\section{Face tracking}

Kolejną bardzo ciekawą metodą badań jest face tracking. Facereader dokonuje pomiaru emocji za pomocą analizy krótkotrwałych i mimowolnych ruchów mięśni twarzy towarzyszących pobudzeniu emocjonalnemu (mikroekspresji). Rejestracja mikroekspresji dokonywana jest przez kamerę dzięki czemu jest to metoda bezinwazyjna i nie powodująca dyskomfortu osoby badanej. Facereader jest w stanie wychwycić 6 podstawowych emocji wg. Ekama: radość, złość, smutek, wstręt, strach, zaskoczenie. Jeżeli w badaniach wykorzystamy Facereader łącznie z eye trackerem możemy dość precyzyjnie określić jaki element materiału badawczego wywołał określoną reakcję emocjonalną [9].

Połączenie powyżej opisanych metod badawczych daje możliwość zebrania bardzo wartościowego materiału badawczego. Wspólna konfiguracja tych urządzeń jest często wykorzystywana w badaniach marketingowych oraz w badaniach z zakresu psychologii konsumenta. Wydaje się, że taki zestaw urządzeń może dokonać także przełomu w badaniach z zakresu psychologii środowiskowej, a w szczególności może mieć olbrzymi wkład w proces likwidacji barier architektonicznych poprzez proces tworzenia przyjaznych przestrzeni mieszkalnych.

\section{Projektowanie i percepcja - formy konwencjonalne}

W odniesieniu do percepcji architektury i jej pośredniego oraz bezpośredniego wpływu na człowieka można stwierdzić, że przykłady znane już człowiekowi można nazwać konwencjonalnymi. Zabudowa jednorodzinna, w której oprócz zabudowy szeregowej oraz bliźniaczej, najbardziej opatrzona dla człowieka jest zabudowa składająca się z pojedynczych domów jednorodzinnych. Tradycyjny układ architektoniczny takiej zabudowy, nieznacznie różniący się w proporcjach i skali elementów występujących w elewacjach, złożony jest z kondygnacji parteru i najczęściej poddasza użytkowego dachu stromego, wielospadowego. Doświetlenie wnętrza domów zaspokajają prostokątne okna bądź coraz częściej stosowane okna typu okna portfenetr.

Coraz częstszym rozwiązaniem jest widoczne na fot. 1, 2, 3 ogrodzenie w formie pełnego muru uniemożliwiające kontakt wzrokowy pomiędzy strefą prywatną właściciela działki z domem a przestrzenią publiczną ulicy osiedla. Takie rozwiązanie formalne ogrodzenia uniemożliwia również tworzenia się stref półpublicznych i półprywatnych. [10] Dążenie do całkowitej prywatności oraz oddzielenia swojej przestrzeni od wspólnej może być jednym z wymiernych bodźców psychologicznych w percepcji środowiska mieszkalnego.

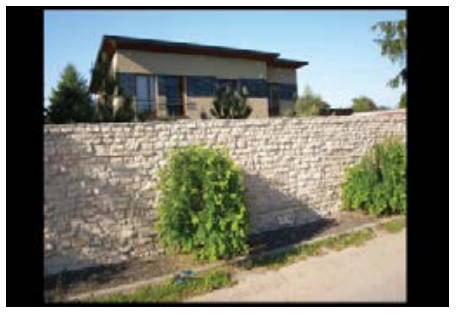

Ryc. 8. Zdjęcia zabudowy jednorodzinnej-dzielnica Wola Justowska - Kraków, autor Wojciech Kocki

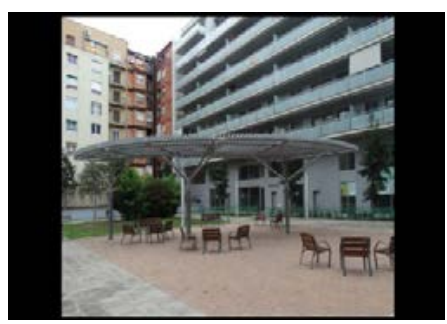

Ryc. 11. Zdjęcia zabudowy wielorodzinnej - Barcelona, autor Wojciech Kocki

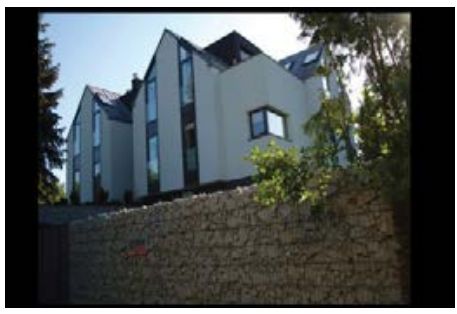

Ryc. 9. Zdjęcia zabudowy jednorodzinnej-dzielnica Wola Justowska-Kraków, autor Wojciech Kocki

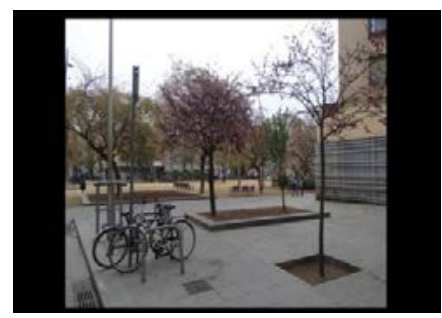

Ryc. 12. Zdjęcia zabudowy wielorodzinnej - Barcelona, autor Wojciech Kocki

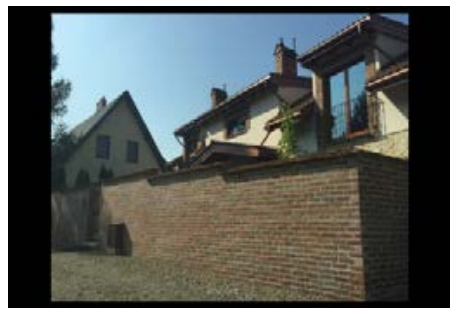

Ryc. 10. Zdjęcia zabudowy jednorodzinnej - dzielnica Konstantynów - Lublin, autor Wojciech Kocki

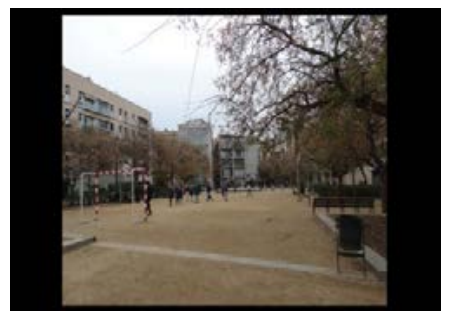

Ryc. 13. Zdjęcia zabudowy wielorodzinnej - Barcelona, autor Wojciech Kocki 
Pomimo tworzenia się widocznych barier pomiędzy przestrzeniami różnymi pod względem charakteru, całkowicie odmienny obraz kształtowania środowiska można zauważyć w zaprojektowanych dziedzińcach osiedli zabudowy wielorodzinnej, która, jeżeli nie są to osiedla prywatne, ogrodzone i odizolowane od przestrzeni miejskiej jest nakierunkowana na każdego mieszkańca bez względu na różnice wieku lub inne fot. 4, 5, 6 .

Kolejnym przykładem miejsc posiadających zbiór cech związanych z percepcją przestrzeni posiadającej odmienny charakter, wspólnej, są miejsca będące otoczeniem obiektów dużej skali jak teatry, muzea, opery, obiekty sztuki i kultury. Otwarta przestrzeń, będąca zarówno tłem jak i dopełnieniem obiektu architektury, jest nieformalna i zazwyczaj nie posiada precyzyjnego scenariusza jej użytkowania. Fot 7-12.

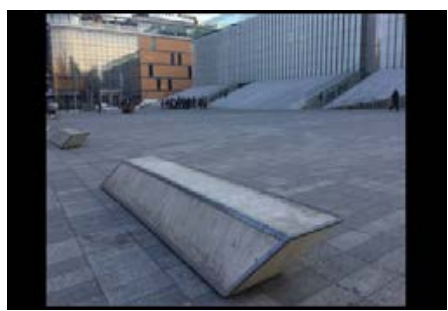

Ryc. 14. Zdjęcia przestrzeni publicznej - Lublin, autor Wojciech Kocki

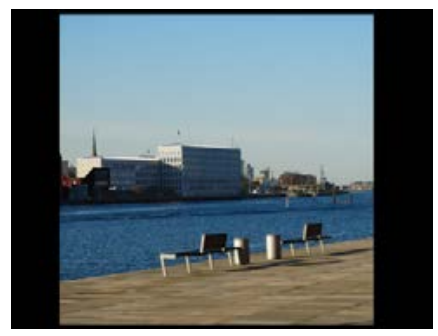

Ryc. 17. Zdjęcia przestrzeni publicznejKopenhaga, autor Wojciech Kocki

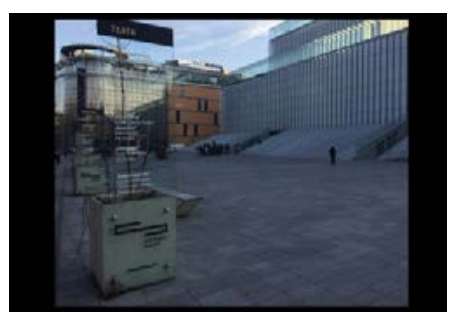

Ryc. 15. Zdjęcia przestrzeni publicznej - Lublin, autor Wojciech Kocki

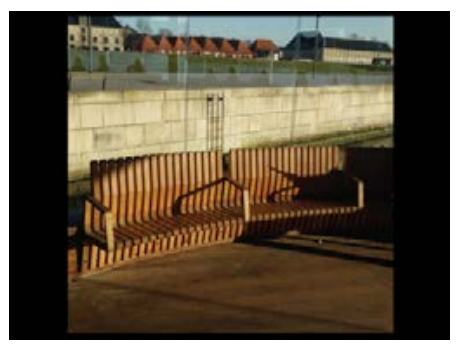

Ryc. 18. Zdjęcia przestrzeni publicznejKopenhaga, autor Wojciech Kocki

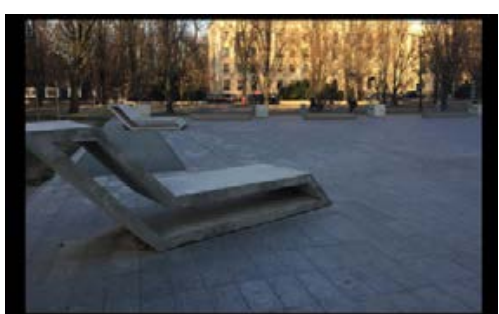

Ryc. 16. Zdjęcia przestrzeni publicznej - Lublin, autor Wojciech Kocki

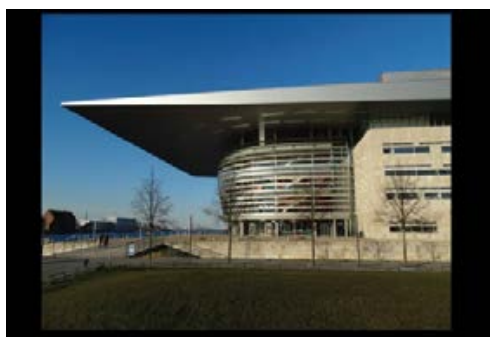

Ryc. 19. Zdjęcia przestrzeni publicznejKopenhaga, autor Wojciech Kocki

Miejskie przestrzenie niewielkich miast, kameralne zaułki ulic wśród historycznej zabudowy są bardzo bliskie człowiekowi ze względu na swoją skalę zabudowy. Człowiek przemierzając te przestrzenie nie jest przytłoczony wysokimi obiektami których percepcja nie jest jednoznacznie możliwa z jednego punktu widokowego. Ulice miasteczek takich ja Angelhol fot. 13-15 lub Delft fot. 16-18 umożliwiają dobrą orientację oraz lokalizację widza w stosunku do całego miasta poprzez charakterystyczne dominanty urbanistyczne tj. kościoły, ratusze itp.

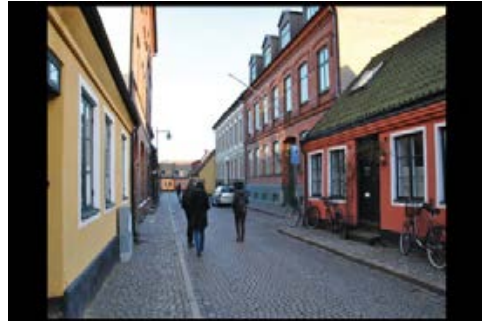

Ryc. 20. Zdjęcia zabudowy jednorodzinnej - Angelholm, Szwecja, autor Wojciech Kocki

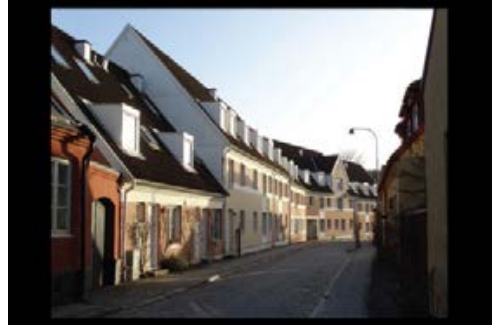

Ryc. 21. Zdjęcia zabudowy jednorodzinnej - Angelholm, Szwecja, autor Wojciech Kocki

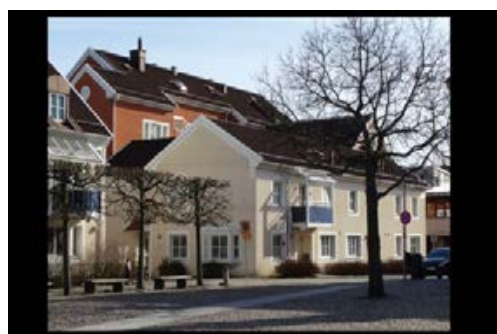

Ryc. 22. Zdjęcia zabudowy jednorodzinnej - Angelholm, Szwecja, autor Wojciech Kocki 


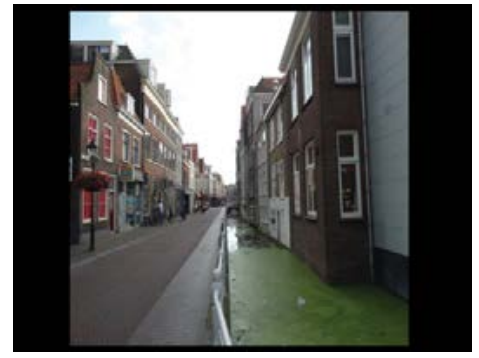

Ryc. 23. Zdjęcia zabudowy jednorodzinnej - Delft, Holandia, autor Wojciech Kocki

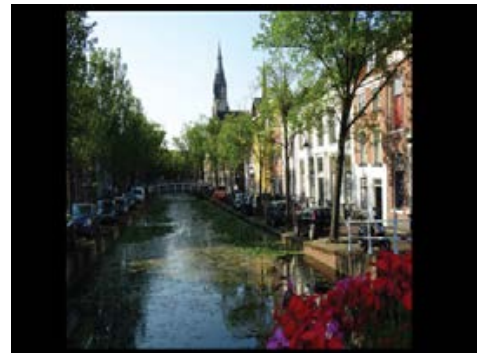

Ryc. 24. Zdjęcia zabudowy jednorodzinnej - Delft, Holandia, autor Wojciech Kocki

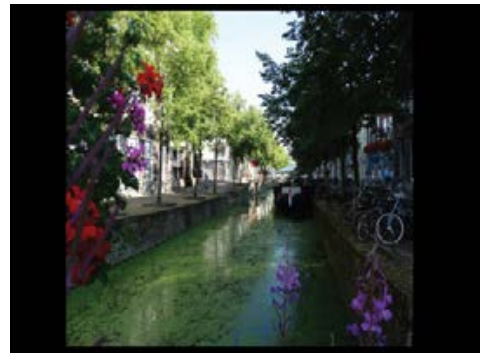

Ryc. 25. Zdjęcia zabudowy jednorodzinnej - Delft, Holandia, autor Wojciech Kocki

Opisane przestrzenie posiadają całkowicie odmienny charakter a ich percepcja zależy od skali zabudowy, ilości zieleni, łatwości w sprecyzowania swojej lokalizacji do np. centrum miasta, scenariusza zachowań oraz możliwości wykorzystania tych przestrzeni w zależności od pory dnia i dostępnych usług. Ważnym elementem przy wyborze przestrzeni mieszkalnych jest niemal wyłącznie status ekonomiczny mieszkańca [11]. Wszystkie te aspekty tworzą zbiór cech pośrednio wpływających na samopoczucie i stan emocjonalny człowieka.

\section{Projektowanie i percepcja - formy parametryczne}

Pojawienie się w XX wieku ruchu dekonstruktywistycznego w architekturze było przełomowym wydarzeniem w sposobie kreowania architektury. Ewoluujący styl był początkiem również dla architektury parametrycznej zawdzięczając połączenie projektowania i programowania komputerowego umożliwiającego uzyskania złożonych kształtów poprzez wykorzystanie informatycznych osiągnięć języków programowania.

Jednym z wielu przykładów jest tymczasowy pawilon wystawowy autorstwa pracowni projektowej Zaha Hadid fot. 19, 20. Jest to obiekt w którym zarówno zewnętrzna elewacja jak i wnętrze posiadają swobodne, obłe, zaokrąglone kształty będąc alternatywnym przykładem dla obiektów z przeważającą liczbą kierunków horyzontalno wertykalnych.

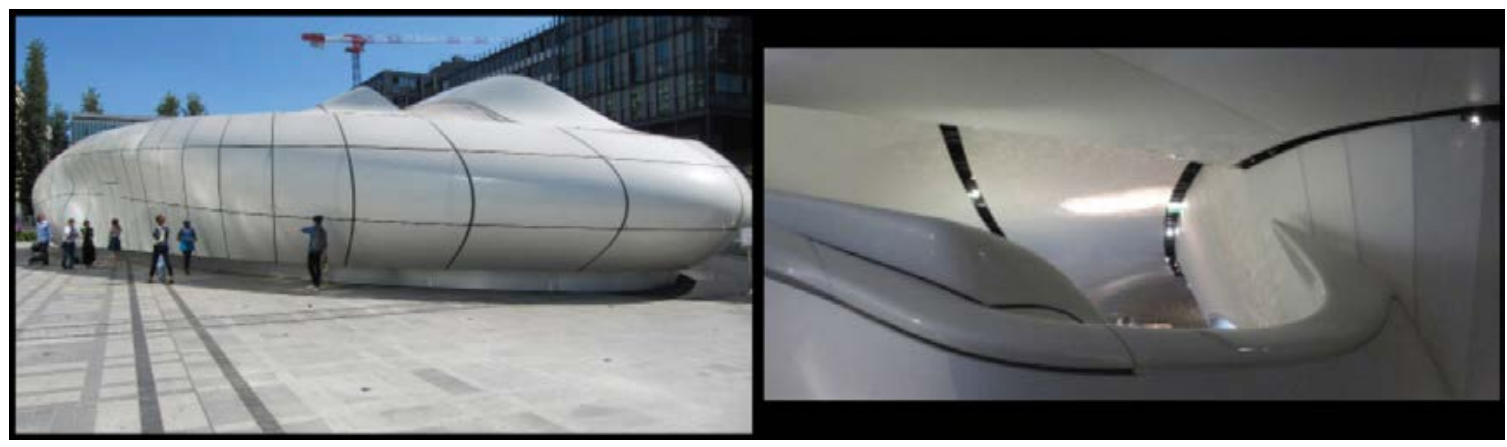

Ryc. 26. Zdjęcia pawilonu wystawowego - Paryż, autor Wojciech Kocki
Ryc. 27. Zdjęcia pawilonu wystawowego - Paryż, autor Wojciech Kocki

Parametrycznie zaprojektowana przestrzeń A fot. 21, 22 jest jednym z przykładów form, które przy wykorzystaniu dostępnych narzędzi programowych mogą kształtować przestrzeń w sposób odmienny niż konwencjonalne projekty. 


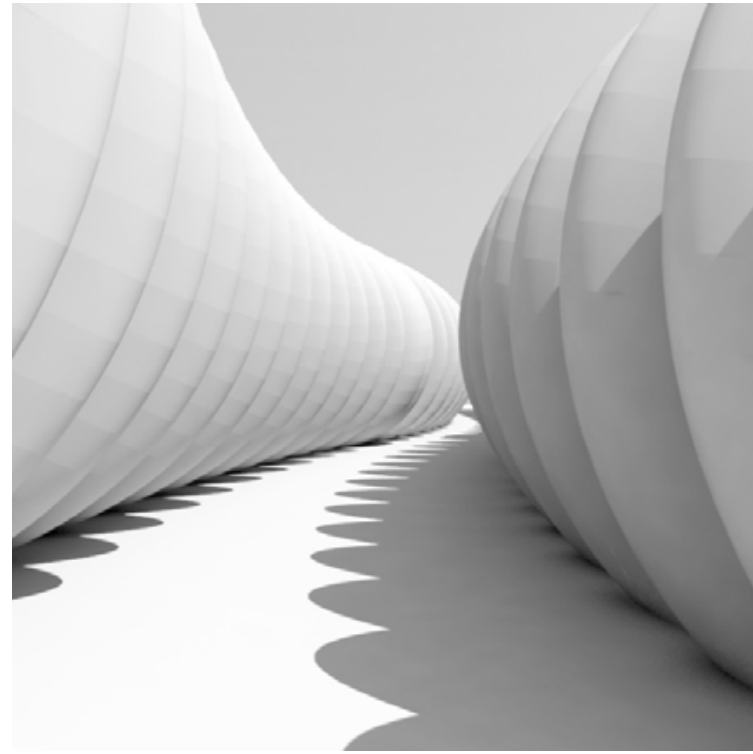

Ryc. 28. Parametrycznie zaprojektowana przestrzeń A, autor Wojciech Kocki

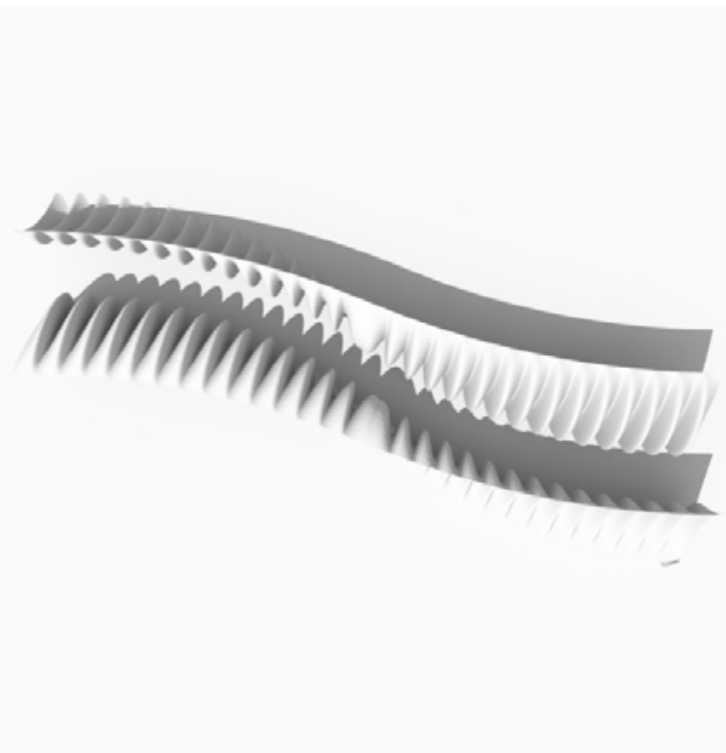

Ryc. 29. Parametrycznie zaprojektowana przestrzeń A - widok z góry, autor Wojciech Kocki

\section{Wnioski}

Obecnie dostępne metody badawcze łączące możliwości percepcyjne trójwymiarowych modeli przestrzennych budowanych w rzeczywistości wirtualnej i poszukiwania efektu ich interakcji na człowieka otwierają nowe możliwości sprecyzowania projektów oraz dopracowania ich pod względem formalnym relatywnie mniejszym kosztem niż budowa fizycznych modeli. Ewoluujące możliwości oprogramowania jako narzędzia pracy architekta a także technologia coraz bardziej zaawansowanych jednostek komputerowych otwierają nowy potencjał do badań wirtualnych, których w efekcie powstająca architektura może znacznie odbiegać od znanych, już istniejących, przykładów.

\section{Literatura}

[1] Bertallanffy L., Perspectives on General Systems Theory. Scientific-Philosophical Studies. E. Taschdjian (eds.), New York 1975.

[2] Mehrabian, A. Russell, J.A., An Approach to Environmental Psychology, M.I.T. Press, Cambridge, Mass, 1974.

[3] Hall E., Ukryty Wymiar, Muza, Warszawa, 2009

[4] Czyński M., Architektura w przestrzeni ludzkich zachowań, Szczecin, 2006.

[5] Kalat J. W., Biologiczne podstawy psychologii, Wydawnictwo Naukowe PWN, Warszawa 2013.

[6] Rowan A. J., Tolunsky E., Primer of EEG With a Mini-Atlas, Butterworth Heinemann, UK, 2003.

[7] Duchowski A., Eye Tracking Methodology, Theory and Practice, Springer, New York 2007.

[8] Francuz P., IMAGIA, W kierunku neurokognitywnej teorii obrazu, Wydawnictwo KUL, Lublin 2013.

[9] Stasiuk K., Maison D., Psychologia konsumenta, Wydawnictwo Naukowe PWN, Warszawa 2015.

[10] Ogrodowczyk A., Polityka mieszkaniowa a współczesne przekształcenia obszarów śródmiejskich - przykład Łodzi, str. 233, PRACE NAUKOWE UNIWERSYTETU EKONOMICZNEGO WE WROCŁAWIU nr 367, 2014.

[11] Gyurkovich J., W poszukiwaniu miejskości - przestrzeń przyjazna, str. 134, Czasopismo Techniczne, Wydawnictwo Politechniki Krakowskiej, Zeszyt 5 rok 107, 2010. 
Abstract: The aim of the article is to show occurring in the urban grid barriers created by man. Barriers distinguished due to their nature, from visual material through space to the intangible psychological relating to the division of society on many levels. The study focus on the quality of the residential environment on the example of single-family housing and multi-family housing in Lublin including the borders of these areas and their interpenetration. Through the analysis of the selected space, based on the psychological aspects and sensual in its reception, shown a set of characteristics that may affect on the quality of the space and its perception within the definition of friendly and hostile space. The results of the analyzes are a prelude to further research in this area.

Keywords: human environment, private space, public space, design, psychology 